\title{
CSR Disclosure on Earnings Management with the Presence of Women in the GCG Structure
}

AFFILIATION:

1,2 Faculty of Economics and Business, Universitas Udayana, Indonesia

\section{*CORRESPONDENCE: \\ alitwahyuningsih97@gmail.com}

THIS ARTICLE IS AVAILABLE IN:

https://ojs.unud.ac.id/index.php/jiab

DOI:

10.24843/JIAB.2020.v15.i02.p11

\section{CITATION:}

Wahyuningsih, A., \& Rasmini, N. K. (2020) CSR Disclosure on Earnings Management with the Presence of Women in the GCG Structure. Jurnal IImiah Akuntansi dan Bisnis, 15(2), 293-307.

\section{ARTICLE HISTORY \\ Received:}

21 January 2020

Revised:

22 June 2020

\section{Accepted:}

28 July 2020

\author{
Alit Wahyuningsih $^{1 *}$, Ni Ketut Rasmini ${ }^{2}$
}

\begin{abstract}
This study examines the effects of Corporate Social Disclosure (CSR) on earnings management with the presence of woman in the Good Corporate Governance (GCG) as moderating variable. The sampling method used was purposive sampling with the criteria of companies listed in the LQ45 index on the Indonesia Stock Exchange and published annual reports and sustainability reports during 2013-2017 period. The data analysis technique used is Moderated Regression Analysis. This study concludes that disclosure of CSR has a positive effect on earnings management. CSR disclosure if accompanied by the presence of women on the audit committee that represents a proxy for the variable of the presence of women in the GCG structure negatively affects earnings management. The results of this study are in line with the theory of the political cost hypothesis which states that companies that have high political costs tend to do earnings management.
\end{abstract}

Keywords: Earnings management, disclosure of corporate social responsibility, good corporate governance.

\section{Introduction}

Earnings management is generally defined as an effort by company managers to intervene or influence the information contained in financial statements in order to fool stakeholders who want to know the condition and performance of a company (Sulistyanto, 2008:4). Earnings management displays the conflict of interests between the principal (shareholders) and the agent (managers), and in this way, the most hypothesis that clarifies this marvel is the agency theory (Diri, 2017). Jensen and Meckling (1976) suggested that in agency theory there is a contractual relationship between the manager as the agent and the business owner as a principle. The relationship between agent and principle can lead to conflicts of interest when shareholders and managers focus on different aspects of the firm's horizon.

Managers who manage the company will know more information in the company and the company's prospects in the future than the shareholder. This unbalanced information will trigger the emergence of 


\section{Wahyuningsih \& Rasmini \\ CSR Disclosure on Earnings Management with the Presence of Women in the GCG Structure}

a condition called information asymmetry. The existence of information asymmetry will encourage managers to present information that is not true, especially if the information is related to the manager's performance measurement (Kori \& Rasmini, 2017). Information asymmetry is a form of agency problem where agency problems will incur agency costs because the principle wants to ascertain whether agents make decisions that are in their interests.

Earnings management pattern is very dependent on the motivation and goals to be achieved by managers. Companies will tend to use accounting methods that can produce financial reports with lower earnings reporting if they have incurred large costs for political interests (Sidartha \& Erawati, 2017). According to Watts \& Zimmerman (1990) who put forward positive accounting theory especially the political cost hypothesis, stating that earnings management practices tend to be carried out on companies that are getting a great political pressure from the government. The political costs of the government in terms of social responsibility are one of the reasons for the practice of earnings management carried out by companies (Ardiani \& Sudana, 2018).

Corporate Social Responsibility (CSR) is a series of activities carried out by the company with the aim as a tangible manifestation that the company is not only faced with responsibilities that are grounded in economic benefits (single bottom line) but also responsible for the economy, environment and social enterprise (triple bottom line). CSR disclosure can be seen through sustainability reports that show a real commitment to social and environmental issues (Kurniawan et al., 2018). However, the existence of this CSR activity can make the management within the company more free to practice earnings management because CSR activities will make a positive response in the eyes of investors and the public so that it can cover up the frauds committed by managers (Putriana et al., 2018). According to the theory of legitimacy, CSR disclosure can shift stakeholder attention over earnings management efforts undertaken by managers so that the community still legitimizes the existence of companies in the community (Setyastrini \& Wirajaya, 2017).

Previous research conducted by several researchers has obtained inconsistent results (thus creating a research gap). Jordaan et al. (2018); Suryani \& Herianti (2015); and Yateno \& Sari (2016) found that companies use CSR as a shield with the intention of covering earnings management to maintain relationships with stakeholders. The findings made by Prior et al. (2008) with a sample of 593 companies from 26 countries stated that managers who has practiced earnings management have two reasons to satisfy the interests of stakeholders namely pre-emptive and entrenchment reasons. While research conducted by Alsaadi et al. (2017); Gras-Gil et al. (2016); Ricardo \& Faisal (2015); and Paramita et al. (2017) found that CSR disclosure had a negative effect on earnings management.

According to Sari \& Putri (2014), the contingency approach explains that one other variable must be developed to answer different research results before. Stakeholder theory states that Good Corporate Governance (GCG) can be a means to reduce agency problems by improving corporate governance. In addition, agency theory is the basis of the concept of GCG which is expected to function as a means to provide investors with confidence that they will receive a return on what they have invested (Pradnyani \& Astika, 2019).

Salancik \& Pfeffer (1978) who developed the resource dependence theory explained the role of the board of directors and the board of commissioners. There are 


\section{Wahyuningsih \& Rasmini \\ CSR Disclosure on Earnings Management with the Presence of Women in the GCG Structure}

two views that explain the role of the board of directors and commissioners in the company, namely the environmental linkage perspective and the internal control function (Yogiswari \& Badera, 2019) while the audit committee assists the board of commissioners in the financial statement oversight function. Khabibah \& Suryatimur (2019) suggests that from the perspective of gender theory, a person's gender determines his behavior.

Many empirical studies have also concluded that there are differences between men and women in risky decision making from two aspects, namely individual character and response to the financial environment. Men are more competitive, optimistic, adventurous, and too confident than women so men are more risk takers than women (Zuckerman, 1994). Jacobsen et al. (2014) argue that women are more pessimistic than men in the ambiguity of financial market pressures. In addition, women have a more pessimistic way of measuring probabilities. That is why women are more conservative than men in financial perceptions and asset allocation decisions. Differences in gender characteristics in corporate governance will improve the quality of reporting. Research by Octaviani \& Kartikaningdyah (2019); Lakhal et al. (2015); and Debnath et al. (2019) show that the presence of women in the board of directors is associated with lower levels of earnings management.

This study adds the presence of women to the GCG structure as a moderating variable because feminist ethical theory states that in relation to corporate governance, women have different views in communicating their opinions so that they will influence the policies to be determined. Appointing the right board member will create good corporate governance, so that it will reflect the increased attention of the company to issues related to corporate sustainability, such as environmental, social, and community issues because it cannot be denied that currently these issues are wrong a strategic issue in supporting the survival of the company. The issue of gender diversity in top management positions is one of the issues of corporate governance that has developed in recent years.

The political cost hypothesis theory explains that when companies incur large political costs, companies tend to do earnings management (Sidartha \& Erawati, 2017). Based on agency theory, CSR disclosure is seen as an opportunistic act. Said to be opportunistic because CSR disclosures made by managers can be one of the actions that provide personal benefits in an effort to improve the manager's career. Management can use CSR disclosure as a shield to deceive the practice of earnings management (Ardiani \& Sudana, 2018). Research conducted by Wardani \& Santi (2018); Muttakin et al. (2015); and Palacios-Manzano et al. (2019) states that Corporate Social Responsibility Disclosure has a positive effect on earnings management. Then the hypothesis formulated in this study is as follows:

$\mathrm{H}_{1}$ : Corporate Social Responsibility Disclosure has a positive effect on earnings management.

So that CSR disclosure is not done to fool stakeholders from earnings management practices carried out by management, a series of mechanisms are needed to direct and control a company so that the company's operations run in accordance with stakeholder expectations. The main purpose of GCG is to prevent misuse of company resources by creating a system of checks and balances. Resource dependence theory also explains that a company's performance will be influenced by the composition of the GCG structure in order to better manage its resources. Psychology 


\section{Wahyuningsih \& Rasmini \\ CSR Disclosure on Earnings Management with the Presence of Women in the GCG Structure}

and management literature have long recognized that there are significant genderbased differences, for example, in leadership style, communication skills, conservatism, risk response, and decision making. Kyaw et al. (2015); Novilia \& Nugroho (2016) and Selahudin et al. (2018) found that the presence of women in the GCG structure could reduce earnings management practices. Then the hypothesis formulated in this study is as follows:

$\mathrm{H}_{2}$ : The presence of women in the structure of Good Corporate Governance weakens the relationship between Corporate Social Responsibility in earnings management.

\section{Research Method}

This research was conducted at companies listed on the Indonesian Stock Exchange (IDX) that provide financial statement information that can be accessed through the official website and the respective company's websites. The reason for determining the location of the study is because companies listed on the IDX publish complete financial statements. The population in this study are companies listed on the LQ45 index on the IDX. The sample in this study are companies that are listed in LQ45 continuously during the 2013-2017 study period.

Earnings management variables in this study were measured using discretionary accruals. Discretionary accruals are accrual components that can be regulated and engineered in accordance with managerial discretion, while nondiscretionary accruals are accrual components that cannot be regulated and engineered in accordance with company policy (Sulistyanto, 2008). Non-discretionary accruals are part of the accruals whose variations can be explained depending on the company's operational activities. To compute discretionary accruals following the modified Jones model equation (1995). The modified Jones model equation was chosen because it was considered the best in detecting earnings management (Ardiani \& Sudana, 2018). This model is widely used in accounting studies because it is considered to be the model that provides the most robust results (Sulistyanto, 2008). The equation model belonging to the Jones model modified according to Agustia (2013) is as follows:

Calculate total accruals:

$$
T A_{i t}=N_{i t}-C F O_{i t}
$$

$\mathrm{TA}_{\mathrm{i}, \mathrm{t}} \quad$ : Total company accrual $\mathrm{i}$ in the time period $\mathrm{t}$

$\mathrm{N}_{\mathrm{it}} \quad$ : Net profit of company i over a period of time $\mathrm{t}$

$\mathrm{CFO}_{\text {it }}$ : Cash flow from operating activities of the company $\mathrm{i}$ in the period time $\mathrm{t}$

$$
\left.N A_{i t}=\beta_{1}\left(1 / A_{i t-1}\right)+\beta_{2}\left(\left(\Delta R E V_{i t}-\Delta R E C_{i t}\right) / A_{i t-1}\right)\right)+\beta_{3}\left(P P E_{i t-1} / A_{i t-1}\right)
$$

$N D A_{i t} \quad$ : Non-discretionary accruals of company $i$ in the time period $t$

$A_{i t-1} \quad$ : Total assets of the company $i$ in the time period $t$

$\triangle R E V_{\text {it }}$ : Change in company income i over a period of time $t$

ECREC $_{\text {it }}$ : Change in company receivables i over a period of time $t$

$\mathrm{PPE}_{\mathrm{it}-1}$ : Company's fixed assets for a period of time $t$

$\beta \quad$ : Regression coefficient 
Calculating Discretionary Accruals (DA):

$$
\mathrm{DA}_{i t}=\mathrm{TA}_{\text {it }}-\mathrm{NDA}_{\text {it }}
$$

$D A_{i t} \quad$ : Discretionary accruals of the company $i$ in the time period $t$

$N A_{i t} \quad$ : Non discretionary accruals of company $i$ in the time period $t$

$\mathrm{TA}_{\mathrm{it}-1} \quad$ : Total company accrual $\mathrm{i}$ in the time period $\mathrm{t}$

CSR is the disclosure of information relating to the environment in the company's annual report. CSR can be measured using the Corporate Social Responsibility Disclosure Index (CSRDI). The CSRDI measurement instrument that will be used in this study refers to the Global Reporting Initiative (GRI) instrument. GRI is a guideline for reporting ongoing reports. The use of the GRI instrument was chosen because it is seen as one of the comprehensive and reliable guidelines because it has been published globally and is supported by a report structure that represents the interests of various parties and has been recognized by companies in the world with a focus on disclosure of economic, social and company environment. The GRI guidelines used for measurement adjust to the GRI guidelines used by companies in preparing sustainability reports. This is intended to get a proportionate CSRDI value according to the total different GRI indicators for each version. Companies in the sample use GRI versions G3, G3.1, G4 and GRI Standards.

Each CSR information disclosure category in the research instrument was given a score of 1 if the information category disclosed was in the continuous report, and a value of 0 if the information category was not disclosed in the sustainability report. After that the scores in each information category in the continuous report are summed to obtain an overall score for each company (Awuy et al., 2016). Measurement using the following formula.

$$
\operatorname{CSRDI}_{\mathrm{j}}=\frac{\Sigma X_{i j}}{N_{i, j}}
$$

$\mathrm{CSRDI}_{\mathrm{j}}=$ Corporate Social Responsibility Index of the company $\mathrm{j}$

$X_{i j} \quad=$ Number of dummy variables in company $\mathrm{j}, 1$ if disclosed, 0 if i not disclosed

$N_{i, j} \quad=$ Number of disclosure indicators that companies should disclose based on GRI

G.3 (79 Indicators), GRI G3.1 (84 Indicators), GRI G4 (91 Indicators), GRI Standards (80 Indicators)

As it has previously been discussed, women can influence the performance of a board group. Measurements were made using the presence of women in the membership of the board of directors, the board of commissioners, and the audit committee board. The presence of women in the GCG structure is measured using a percentage of the number of female directors in the company to show the proportion of women in the GCG structure. This can be seen from the annual financial statements published by companies on the IDX.

$$
\text { WOMAN }=\frac{\mathrm{DD} / D K / K A}{\text { Total Director } / \text { Commisioner / Audit Commitee }}
$$

WOMANj : Women's Presence in GCG Structure Company index $\mathrm{j}$

DD : Number of women present on the board of directors, 0 if there is no DD

DK : Number of women in the board of commissioners, 0 if there is no DK

KA : Number of women present on the audit committee, 0 if there is no KA 
Moderated Regression Analysis or multiple linear regression analysis aims to determine the role of a variable that can strengthen or weaken the correlation between an independent variable and the dependent variable. MRA is a special application in multiple linear regression analysis where the regression equation contains interaction elements (multiplication of two or more independent variables) with the equation formula as did Ardiani \& Sudana (2018) with modifications as follows:

$\mathrm{Y} \quad$ : Earnings Management

$$
Y=\alpha+\beta_{1} X+\beta_{2} M+\beta_{3} X . M
$$

$\alpha \quad$ : Constants

$\beta_{1}, \beta_{2}, \beta_{3}$ : Coefficient of regression for independent variables

$X \quad$ : CSR Disclosure

M : The existence of women in the GCG structure

$\varepsilon \quad: \quad$ Error term, the estimator error rate in the study

\section{Result and Discussion}

Factor analysis in this study uses a type of exploratory factor analysis that aims to reduce a number of variables to one factor that will represent moderation in this study, namely the presence of women in the GCG structure. Table 1 . shows KMO test results are $0.500(\geq 0.50)$ and the Barlett's Sphericity test is significant at 0.386 which is greater than 0.05 which means the results of the factor analysis cannot be continued. However, it shows the proxy for the existence of women in the board of commissioners (DK) has a value of communalities only reached 0.007 (smaller than 0.50 ), where the smaller the communalities of a variable, means the weaker relationship with the factors formed and must be excluded (Utama, 2016:206).

Table 2. shows the results of the KMO test of 0.500 and the Barlett's Sphericity test are significant at 0.048 that is smaller than 0.05 that means the results of the factor analysis can be continued. An anti-image correlation result shows that all proxies have a value of more than 0.50 . Table 3 . shows that the two variables that make up the factors have the same loading factor that is 0.811 so that one can be chosen as a variable that represents the existence of women in the GCG structure. Based on Table 4. it can be seen that the Durbin-Watson value of 1.649 with a significant level of $5 \%$ for $n=40$ and $\mathrm{k}=3$ values of $\mathrm{dL}=1.338$ and $\mathrm{dU}=1.658$ so $\mathrm{a} 4-\mathrm{dU}=2.334$ value is also obtained.

Table 1. Validity Value, Value of Loading Factor, and Communalities Factor Analysis in Analysis 1

\begin{tabular}{lcccc}
\hline \multicolumn{1}{c}{ Assessment criteria } & Cut-off Value & Proxy & Loading Factor & Communalities \\
\hline KMO (Kaiser-Meyer- & 0.500 & DD & 0.797 & 0.635 \\
Olkin) & & & & \\
$X^{2}$ (Chi Square) & 3.038 & DK & 0.086 & 0.007 \\
Significance Probability & 0.386 & KA & -0.799 & 0.639 \\
Anti-Image & & & & \\
DD & 0.500 & & & \\
DK & 0.530 & & & \\
KA & 0.500 & & & \\
\hline
\end{tabular}

Source: Processed Data, 2019 
CSR Disclosure on Earnings Management with the Presence of Women in the GCG Structure

Table 2. Validity Value in Factor Analysis in Analysis 2

\begin{tabular}{lc}
\hline \multicolumn{1}{c}{ Assessment criteria } & Cut-off Value \\
\hline KMO (Kaiser-Meyer-Olkin) & 0.500 \\
X $^{2}$ (Chi Square) & 3.906 \\
Significance Probability & 0.048 \\
Anti-Image & \\
DD & 0.500 \\
KA & 0.500 \\
\hline
\end{tabular}

Source: Processed Data, 2019

So conclusions can be drawn if using a proxy for the existence of women in directors (DD) does not meet the requirements of static testing. So the proxy chosen is the presence of women on the audit committee (KA) because it is fit with the model that will be explained through the classical assumption test.

Descriptive statistics are presented to provide information about the characteristics of research variables consisting of the number of sample observations, maximum values, minimum values, mean values and standard deviations. Table 5 shows earnings management $(\mathrm{Y})$ has the lowest value (minimum) of -0.1023 , namely PT. United Tractors Tbk. (UNTR) in 2015 means that there are companies that manage earnings by lowering their profits by $10.23 \%$. The highest value (maximum) of 0.3021 is PT. AKR Corporindo Tbk. (AKRA) in 2013 means that there are companies that manage earnings by increasing their profits by $30.21 \%$. Variable Disclosure Corporate Social Responsibility $(\mathrm{X})$ has the lowest value (minimum) of 0.1000 , namely CSR disclosure from PT. Bank Rakyat Indonesia Tbk. 2016. The highest value (maximum) of 1.0000 is CSR disclosure from the company PT. Indocement Tunggal Prakarsa Tbk. in 2013. The mean (mean) of CSR disclosures was 0.3278 or $32.78 \%$. The variable of the existence of women in the structure of Good Corporate Governance (M) which in this study is proxied by the presence of women on the audit committee (M3) based on the factor analysis that has been done previously shows a minimum value of 0.0000 and a maximum value of 0.6667 .

Based on the results of the Moderated Regression Analysis as presented in Table 6. the structural equation is as follows:

$$
\mathrm{Y}=0.044+0.027 \mathrm{X}+0.011 \mathrm{M}-0.017 \mathrm{X} . \mathrm{M}
$$

First hypothesis $\left(\mathrm{H}_{1}\right)$ states that the disclosure of Corporate Social Responsibility has a positive effect on earnings management. The results show that $\mathrm{H}_{1}$ is accepted, that there is a positive effect between Corporate Social Responsibility disclosure and earnings management. The earnings management increases if the company discloses a higher Corporate Social Responsibility. Conversely, the earnings management decreases if the company discloses a lower Corporate Social Responsibility. The results of this study are in line with research conducted by (Wardani \& Santi, 2018) which states that companies that conduct CSR disclosures intensively and regularly tend to try to cover up some corporate actions.

Table 3. Value of Loading Factor and Communalities in Factor Analysis in Analysis 2

\begin{tabular}{ccc}
\hline Proxy & Loading Factor & Communalities \\
\hline DD & 0.811 & 0.657 \\
KA & -0.811 & 0.657
\end{tabular}

Source: Processed Data, 2019 
Wahyuningsih \& Rasmini

CSR Disclosure on Earnings Management with the Presence of Women in the GCG Structure

Table 4. Autocorrelation Test Results

\begin{tabular}{cccccc}
\hline $\begin{array}{c}\text { Mode } \\
\mathrm{I}\end{array}$ & $\mathrm{R}$ & $\begin{array}{c}\mathrm{R} \\
\text { Square }\end{array}$ & $\begin{array}{c}\text { Adjusted } \mathrm{R} \\
\text { Square }\end{array}$ & $\begin{array}{c}\text { Std. Error of } \\
\text { the Estimate }\end{array}$ & Durbin-Watson \\
\hline 1 & $0,495^{\mathrm{a}}$ & 0,245 & 0,183 & 0,447659 & 1,649 \\
\hline
\end{tabular}

Source: Processed Data, 2019

For example, the Enron company that carries out massive earnings management turns out to be a company with high CSR performance (Ratmono et al., 2015). This results also in line with the theory of political cost hypothesis (Watts \& Zimmerman, 1990).

Second hypothesis $\left(\mathrm{H}_{2}\right)$ states that the presence of women in the structure of Good Corporate Governance weakens the relationship between Corporate Social Responsibility in earnings management. The results show that $\mathrm{H}_{2}$ is accepted, this shows that the disclosure of CSR when accompanied by the presence of women in the GCG structure has a negative effect on earnings management. This study found the same results with research from (Susanto, 2016) which found there were contingency factors that influenced the relationship between CSR disclosure and earnings management. The contingency factor is the women's audit committee, which is the supervisor of the company's management to carry out company activities in accordance with the wishes of the principle in this case the shareholders, which will increase the value of the company. With supervision it is expected that the women's audit committee negatively influences the relationship between disclosure of social responsibility, the environment, and earnings management. This is in line with the resource dependence theory (Salancik \& Pfeffer, 1978) and gender perspective theory (Eagly, 1987). Theory of political costs (political cost hypothesis) which states that high political costs tend to provide opportunities to practice earnings management.

CSR disclosure is also a form of manager's responsibility as an agent in fulfilling the principle. Companies that make CSR disclosures create a good image for the company, are socially responsible, and can be trusted in the eyes of shareholders. Publishing CSR disclosures is one way for companies to inform them that they are responsible for these issues (Yip et al., 2011). CSR disclosure can help managers to meet the expectations of their stakeholders because the existence of the company requires support, so the company's activities should also consider the approval of stakeholders. With the disclosure of CSR will increase the value of the company from the impact of CSR activities undertaken by the company and minimize losses for stakeholders so that the company can obtain long-term benefits.

Table 5. Descriptive Statistics of Results Samples ( $N=40)$

\begin{tabular}{lcrrrr}
\hline & $\mathrm{N}$ & Minimum & Maximum & Mean & Std. Deviation \\
\hline Earning Management (Y) & 40 & -0.1023 & 0.3021 & 0,0338 & 0.0078 \\
Corporate Social & 40 & 0.1000 & 1.0000 & 0.3278 & 0.1683 \\
Responsibility (CSR) & & & & & \\
Disclosure (X) & & & & & \\
KA (M3) & 40 & 0.0000 & 0.6667 & 0.1688 & 0.1901 \\
Valid N (listwise) & 40 & & & & \\
\hline
\end{tabular}

Source: Processed Data, 2019 
Wahyuningsih \& Rasmini

CSR Disclosure on Earnings Management with the Presence of Women in the GCG Structure

Table 6. Moderated Regression Analysis (MRA) Test Results

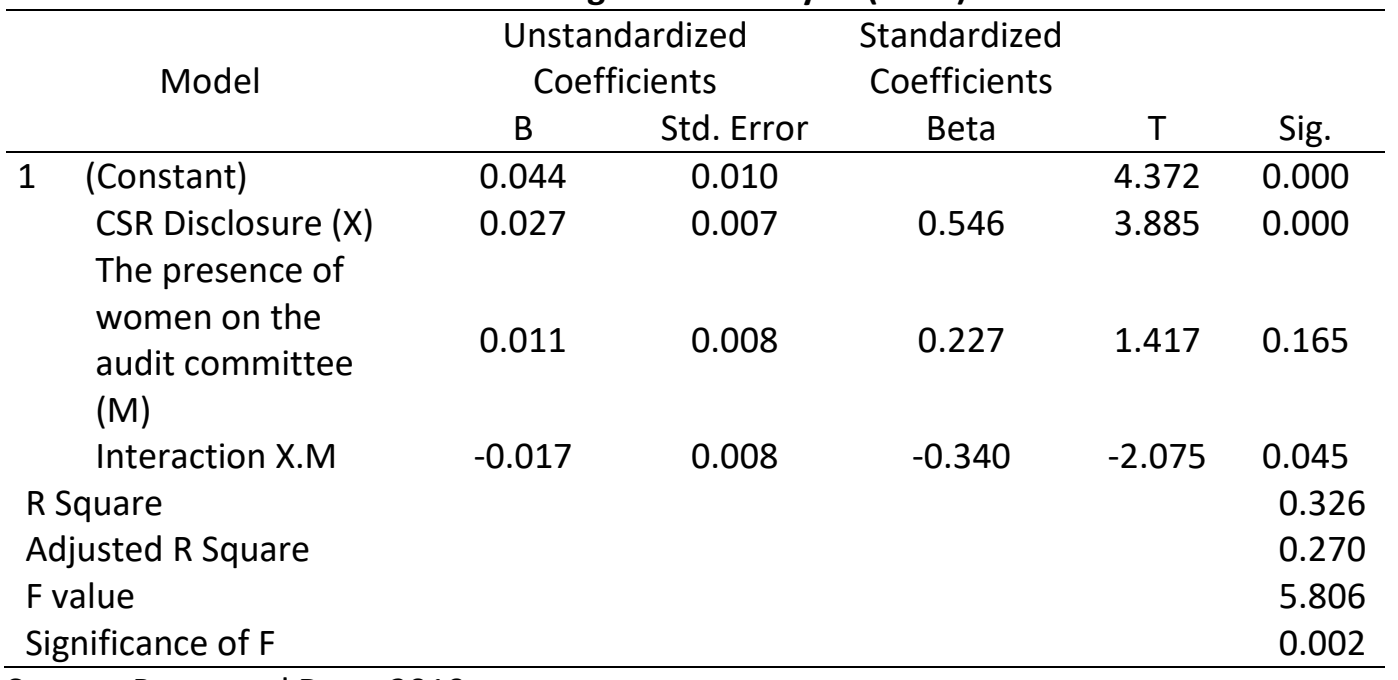

Source: Processed Data, 2019

Research conducted by Prior et al. (2008) states that managers who practice earnings management have two reasons to satisfy the interests of stakeholders namely pre-emptive and entrenchment reasons. First, the pre-emptive reason: managers anticipate the attitude of activism from stakeholders that can disrupt their position in the company when managing earnings. A good way to avoid such activism is to satisfy the interests of stakeholders. Second, the reason for entrenchment: managers tend to collude with other stakeholders as a hedging strategy against the initiative of shareholders, whose long-term interests may be disrupted by earnings management practices.

Wardani \& Santi (2018) stated that the public believes that companies that carry out high CSR activities are unlikely to carry out less ethical actions such as earnings management. These conditions indicate that the higher the CSR of a company, the higher the earnings management actions taken. Palacios-Manzano et al. (2019) argue that managers who perform earnings management can use CSR information to disguise their opportunistic behavior. The motivation of managers to engage in CSR is always driven by some kind of personal interest, such as hiding earnings management, advancing their careers or other personal agendas.

An organization, in this case a company, can be formed on every binding contract by opportunistic actors. The contract will incur costs for the company. Every number reported in accounting has economic consequences if it affects the tax to be paid or the subsidies to be received by companies, especially large companies that are publicly highlighted. To overcome this, companies will try to reduce the profits they report with the aim of reducing political costs, one of which is by carrying out CSR activities. CSR disclosures are used by managers to cover earnings management actions that have been taken. Declining profits will reduce the tendency to transfer political costs.

The test results show that CSR disclosure if accompanied by the presence of women in the GCG structure negatively affects earnings management. These results are in accordance with the expected hypothesis so $\mathrm{H}_{2}$ is accepted. This study found the same results with research from Susanto (2016) and Zalata et al. (2018). Zalata et al. (2018) states the presence of women on the audit committee is very effective in 


\section{Wahyuningsih \& Rasmini \\ CSR Disclosure on Earnings Management with the Presence of Women in the GCG Structure}

suppressing earnings management practices. This might be due to the nature of women who are more afraid to take risks, resist risks, and be more careful and ethical than men. With these conditions will provide positive results related to the activities of overseeing financial reports and produce better quality corporate governance reports and reduce misstatements that occur. Susanto (2016) found there are contingency factors that influence the relationship between CSR disclosure and earnings management. The contingency factor is the women's audit committee, which is the supervisor of the company's management to carry out company activities in accordance with the wishes of the principle in this case the shareholders, which will increase the value of the company. With supervision it is expected that the women's audit committee negatively influences the relationship between disclosure of social responsibility, the environment, and earnings management.

This finding is in line with the agency theory developed by Jensen \& Meckling, (1976) which states that there is a working relationship between the party that gives authority (principle), namely the owner or shareholder and the party that receives the authority (agent), namely the manager, in the form of a cooperation contract. Associated with earnings management, managers holding the role of agents will find out more company information because they hold the responsibility of managing the company compared to principle or shareholders. The manager will provide information that illustrates the performance of the company through financial reporting instruments. The financial statements will be used as a basis for evaluating the contact between principle and agent by assessing whether the agent in this case the manager has done his obligations properly and is worthy of his rights. In order to maximize its utility, managers tend to display financial reports in such a way as to match the amount desired to obtain performance appraisals as expected.

Companies with high political costs tend to do earnings management because they need to avoid the possibility that they will be targeted by adverse political actions. In this case managers tend to reduce earnings and report higher CSR disclosures to hide earnings management actions. Managers use CSR as a shield to reduce dissatisfaction or suspicion from stakeholders, the manager uses CSR as a shield (Sabatini \& Sudana, 2019). Under these conditions a control structure is needed that can align the different interests between principle and agent.

The concept of Corporate Governance aims to align the interests between principle and agent so as to avoid inequality of information which results in agency problems and makes the company healthier. Good corporate governance is defined as a series of mechanisms used to direct and control a company so that the company's operations run in accordance with stakeholder expectations.

Feminist ethical theory focuses on relationships (socialist) when working on a task. In contrast to the masculinist view which emphasizes the rights and obligations personally (individualist) in a task. Therefore, the presence of women in the GCG structure will provide a better work atmosphere.

Diversity prevents a person or group of people from dominating the decision making process and thereby reducing agency problems. Abad et al. (2017) suggested that the composition of a more diverse GCG structure can be considered a better control structure for managers because diversity tends to increase the independence of the GCG structure. The results of a study conducted by Ernst and Young (2009) state that board groups with greater diversity tend to have better performance than board groups 


\section{Wahyuningsih \& Rasmini \\ CSR Disclosure on Earnings Management with the Presence of Women in the GCG Structure}

that are dominated by one gender, even though the people on them have higher capabilities.

Gender diversity in the board of directors has an influence on company performance so it will tend to reduce violations of financial statement rules. Feminine traits of women carry characteristics in organizations, influencing leadership styles and decision-making styles (Maula \& Rakhman, 2018). In the context of research on the impact of women commissioners on earnings management, research conducted by Peni \& Vähämaa (2010) in Setiawan (2018) shows that women in the position of financial director are more conservative in their policies, so the level of earnings management is low. While the existence of the audit committee is expected to reduce earnings management activities which will further affect earnings quality.

\section{Conclusion}

This research has been able to provide empirical evidence that Corporate Social Responsibility Disclosure has a positive effect on earnings management. This means that companies with a high level of Corporate Social Responsibility Disclosure tend to practice high earnings management. Managers can use CSR disclosure as a self-defense strategy (entrenchment strategy) to anticipate dissatisfaction when managers manage company profits and report company performance that is not in line with stakeholder's expectations. The study also found that the presence of women in the structure of Good Corporate Governance weakens the relationship between Corporate Social Responsibility in earnings management. The test results show that CSR disclosure if accompanied by the presence of women in the GCG structure negatively affects earnings management. The presence of women in the GCG structure in this study is represented by the presence of women on the audit committee, it will provide better supervision and be able to align the interests of management and stakeholders.

This study contributes to the literature because this study uses the presence of women in the GCG structure as moderating variables that were not included by previous researchers in the study. This study delivers information for earnings management, Corporate Social Responsibility Disclosure, Good Corporate Governance, and gender diversity as additional independent variables used. This research is expected to contribute to investors in analyzing the company by looking at sustainability report and annual report especially in Good Corporate Governance structure section in making investment decisions. Investors can also pay attention to how diverse the proportions in the GCG structure that reflects how the GCG structure is form a decision and provide oversight to the company. This study has several limitations. First, the sample obtained in the study is still limited because many companies do not publish sustainability report regularly every year. Future research could expand the sample not only limited to companies listed in the LQ45 index and use ISO26000 as CSRDI measurement instrument so there will be more sample used in the research. Second, earnings management variables in this study were only measured using discretionary accruals while there is a possibility that companies using real earnings management. Future research could consider the use of earnings management proxy through real activity. Manager's choice for managing earnings management not only limited with accruals but also can be done through real activities. Earnings management through real activity is 


\section{Wahyuningsih \& Rasmini}

CSR Disclosure on Earnings Management with the Presence of Women in the GCG Structure

more difficult to detect, so managers prefer to use this method in earnings management.

\section{References}

Abad, D., Lucas-Pérez, M. E., Minguez-Vera, A., \& Yagüe, J. (2017). Does gender diversity on corporate boards reduce information asymmetry in equity markets? $B R Q$ Business Research Quarterly, 20(3), 192-205. https://doi.org/10.1016/j.brq.2017.04.001

Agustia, D. (2013). Pengaruh Faktor Good Corporate Governance, Free Cash Flow, dan Leverage Terhadap Manajemen Laba. Jurnal Akuntansi Dan Keuangan, 15(1), $27-$ 42. https://doi.org/10.9744/jak.15.1.27-42

Alsaadi, A., Ebrahim, M. S., \& Jaafar, A. (2017). Corporate Social Responsibility, ShariahCompliance, and Earnings Quality. Journal of Financial Services Research, 51(2), 169-194. https://doi.org/10.1007/s10693-016-0263-0

Ardiani, N. L. N., \& Sudana, I. P. (2018). Pengaruh Corporate Social Responsibility Pada Manajemen Laba. E-Jurnal Akuntansi Universitas Udayana, 24(3), 2333-2359. https://doi.org/10.24843/EJA.2018.v24.i03.p26

Debnath, N. C., Patnaik, B. C. M., \& Satpathy, I. (2019). Female Directorship and Real Earnings Management in Bangladesh: Towards an Analytical Assessment. Management Science Letters, 9(9), 1723-1740. https://doi.org/10.5267/j.msl.2019.6.018

Diri, M. El. (2017). Introduction to Earnings Management. Switzerland: Springer International Publishing AG 2018. https://doi.org/10.1007/978-3-319-62686-4_3

Eagly, A. H. (1987). Sex Differences in Social Behavior: A Social-Role Interpretation. Hillsdale: Erlbaum.

Gras-Gil, E., Palacios Manzano, M., \& Hernández Fernández, J. (2016). Investigating the relationship between corporate social responsibility and earnings management: Evidence from Spain. BRQ Business Research Quarterly, 19(4), 289-299. https://doi.org/10.1016/j.brq.2016.02.002

Jacobsen, B., Lee, J. B., \& Zhang, C. (2014). Gender Differences in Optimism and Asset Allocation. Journal of Economic Behavior \& Organization, 107, 630-651. https://doi.org/10.1016/j.jebo.2014.03.007

Jensen, M. C., \& Meckling, W. H. (1976). Theory of the firm: Managerial behavior, agency costs and ownership structure. Journal of Financial Economics. https://doi.org/10.1016/0304-405X(76)90026-X

Jordaan, L. A., de Klerk, M., \& de Villiers, C. J. (2018). Corporate social responsibility and earnings management of South African companies. South African Journal of Economic and Management Sciences, 21(1), 1-13. https://doi.org/10.4102/sajems.v21i1.1849

Khabibah, N. A., \& Suryatimur, K. P. (2019). Gender, Budaya dan Kualitas Laba. Prosiding Seminar Nasional Dan Call For Papers Fakultas Ekonomi Universitas Tidar, 217-231.

Kori, M. O. D., \& Rasmini, N. K. (2017). Struktur Good Corporate Governance sebagai Pemoderasi Pengaruh Asimetri Informasi pada Manajemen Laba. E-Jurnal Akuntansi Universitas Udayana, 21(1), 144-172.

Kurniawan, T., Sofyani, H., \& Rahmawati, E. (2018). Pengungkapan Sustainability Report dan Nilai Perusahan: Studi Empiris di Indonesia dan Singapura. Kompartemen: Jurnal Ilmiah Akuntansi, 16(1), 1-20. 


\section{Wahyuningsih \& Rasmini \\ CSR Disclosure on Earnings Management with the Presence of Women in the GCG Structure}

https://doi.org/10.30595/kompartemen.v16i1.2100

Kyaw, K., Olugbode, M., \& Petracci, B. (2015). Does gender diverse board mean less earnings management? Finance Research Letters, 14, 135-141. https://doi.org/10.1016/j.frl.2015.05.006

Lakhal, F., Aguir, A., Lakhal, N., \& Malek, A. (2015). Do Women on Boards and in Top Management Reduce Earnings Management? Evidence in France. Journal of Applied Business Research, 31(3), 1107-1118.

Maula, K. A., \& Rakhman, A. (2018). Pengaruh Board Diversity (CEO Wanita, CFO Wanita, Proporsi Dewan Komisaris Wanita, Proporsi Komite Audit Wanita) Terhadap Pelanggaran Aturan Laporan Keuangan. Journal of Applied Accounting and Taxation, 3(01), 431-445.

Muttakin, M. B., Khan, A., \& Azim, M. I. (2015). Corporate social responsibility disclosures and earnings quality Are they a reflection of managers' opportunistic behavior? Managerial Auditing Journal, 30(3), 277-298. https://doi.org/10.1108/maj-02-2014-0997

Novilia, O., \& Nugroho, P. I. (2016). Pengaruh Manajemen Puncak Wanita Terhadap Manajemen Laba. Dinamika Akuntansi, Keuangan Dan Perbankan, 5(1), 27-45.

Octaviani, S., \& Kartikaningdyah, E. (2019). Effect of Corporate Governance (Woman's Executive Board), Company Size and Leverage on Profit Managemen. Journal of Applied Managerial Accounting, 3(1), 58-72.

Palacios-Manzano, M., Gras-Gil, E., \& Santos-Jaen, J. M. (2019). Corporate social responsibility and its effect on earnings management: an empirical research on Spanish firms. Total Quality Management and Business Excellence, 0(0), 1-17. https://doi.org/10.1080/14783363.2019.1652586

Paramita, N. N. E. Y., Sujana, E., \& Herawati, N. T. (2017). Pengaruh Financial Distress, Risiko Litigasi dan Pengungkapan Corporate Social Responsibility terhadap Manajemen Laba. E-Journal Akuntansi S1, 1.

Peni, E., \& Vähämaa, S. (2010). Female executives and earnings management. Managerial Finance, 36(7), 629-645. https://doi.org/10.1108/03074351011050343

Pradnyani, I. A. D. C., \& Astika, I. B. P. (2019). Moderasi Good Corporate Governance Terhadap Pengaruh Risiko Perusahaan Pada Manajemen Laba. E-Jurnal Akuntansi Universitas Udayana, 26(2), 937-965.

https://doi.org/10.24843/EJA.2019.v26.i02.p04

Prior, D., Surroca, J., \& Tribó, J. A. (2008). Are socially responsible managers really ethical? Exploring the relationship between earnings management and corporate social responsibility. Corporate Governance: An International Review, 16(3), 160177. https://doi.org/10.1111/j.1467-8683.2008.00678.x

Putriana, M., Artati, S., \& Utami, V. J. (2018). Pengaruh Corporate Social Responsibility Terhadap Manajemen Laba Dengan Leverage Dan Growth Sebagai Variabel Control Pada Industri Farmasi Yang Terdaftar Di Bursa Efek Indonesia. J-MAS (Jurnal Manajemen Dan Sains), 3(2), 226. https://doi.org/10.33087/jmas.v3i2.60

Ratmono, D., Purwanto, A., \& Cahyonowati, N. (2015). Hubungan Tingkat Pengungkapan dan Kinerja Corporate Social Responsibility Serta Manajemen Laba: Pengujian Teori Ekonomi dan Sosio-Politis. Jurnal Akuntansi Dan Keuangan, 16(2), 63-73. https://doi.org/10.9744/jak.16.2.63-73

Ricardo, D. M., \& Faisal. (2015). Pengaruh Pengungkapan Corporate Social Responsibility Terhadap Praktik Manajemen Laba. Diponegoro Journal of Accounting, 4(2), 33-42. 


\section{Wahyuningsih \& Rasmini \\ CSR Disclosure on Earnings Management with the Presence of Women in the GCG Structure}

Sabatini, K., \& Sudana, I. P. (2019). Pengaruh Pengungkapan Corporate Social Responsibility Pada Nilai Perusahaan Dengan Manajemen Laba Sebagai Variabel Moderasi. Jurnal Ilmiah Akuntansi Dan Bisnis, 14(1), 56-69. https://doi.org/10.24843/jiab.2019.v14.i01.p06

Salancik, G. R., \& Pfeffer, J. (1978). A Social Information Processing Approach to Job Attitudes and Task Design. Administrative Science Quarterly, 23(2), 224-253. https://doi.org/10.2307/2392563

Sari, A. A. I. P., \& Putri, I. G. A. M. A. D. (2014). Pengaruh Mekanisme Corporate Governance Pada Manajemen Laba. E-Jurnal Akuntansi Universitas Udayana, 8(1), 94-104.

Selahudin, N. F., Fauzan, M., \& Ahmad, M. (2018). Do Female Director , Audit Quality and Audit Committee Characteristics Influence the Earnings Management ? Global Business and Management Research: An International Journal, 10(3), 130-140.

Setiawan, D. (2018). Karakteristik Dewan Komisaris dan Manajemen Laba: Bukti pada Peristiwa Penawaran Saham Perdana. Jurnal Siasat Bisnis, 22(2), 164-181. https://doi.org/10.20885/jsb.vol22.iss2.art4

Setyastrini, N. L. P., \& Wirajaya, I. G. A. (2017). Intensitas Pengungkapan Corporate Social Responsibility: Pengujian dengan Manajemen Laba AkruaL dan Riil. E-Jurnal Akuntansi Universitas Udayana, 19(1), 337-366.

Sidartha, A. R. M., \& Erawati, N. M. A. (2017). Pengaruh Ukuran Perusahaan Dan Risiko Keuangan Pada Praktik Perataan Laba Dengan Variabel Pemoderasi Jenis Industri. E-Jurnal Akuntansi Universitas Udayana, 20(2), 1103-1132. https://doi.org/10.24843/EJA.2017.v20.i02.p09

Sulistyanto, S. (2008). Manajemen Laba, Teori dan Model Empiris. Jakarta: Grasindo.

Suryani, A., \& Herianti, E. (2015). Pengaruh Pengungkapan Tanggung Jawab Sosial Perusahaan terhadap Koefisen Respon Laba dan Manajemen Laba. Simposium Nasional Akuntansi, 11, 50-63.

Susanto, Y. K. (2016). The Effect of Audit Committees and Corporate Governance on Earnings Management: Evidence from Indonesia Manufacturing Industry. International Journal of Business, Economics and Law, 10(1), 32-37.

Utama, S. M. (2016). Buku Ajar Aplikasi Analisis Kuantitatif. Denpasar: Fakultas Ekonomi Universitas Udayana.

Wardani, D. K., \& Santi, D. K. (2018). Pengaruh Tax Planning, Ukuran Perusahaan, Corporate Social Responsibility (CSR) terhadap Manajemen Laba. Jurnal Akuntansi, 6(1), 11-24.

Watts, R. L., \& Zimmerman, J. L. (1990). Accounting Year Theory : Ten Perspective. Review Literature And Arts Of The Americas, 65(1), 131-156. https://doi.org/10.2307/247880

Yateno, \& Sari, G. P. (2016). Penguji Manipulasi Laba Real Pada Pengungkapan Corporate Social Responsibility (Studi Empiris Pada Perusahaan Manufaktur Di Bursa Efek Indonesia). Jurnal Akuisisi, 12(2), 26-36. https://doi.org/10.24127/akuisisi.v12i2.106

Yip, E., Staden, C. Van, \& Cahan, S. (2011). Corporate Social Responsibility Reporting and Earnings Management: The Role of Political Costs. Australasian Accounting Business and Finance Journal, 5(3), 17-34.

Yogiswari, N. L. P. P., \& Badera, I. D. N. (2019). Pengaruh Board Diversity Pada Nilai Perusahaan Dalam Perspektif Corporate Governance. E-Jurnal Akuntansi, 26, 2070. 


\section{Wahyuningsih \& Rasmini}

CSR Disclosure on Earnings Management with the Presence of Women in the GCG Structure

https://doi.org/10.24843/eja.2019.v26.i03.p15

Zalata, A. M., Tauringana, V., \& Tingbani, I. (2018). Audit Committee Financial Expertise, Gender, and Earnings Management: Does Gender of the Financial Expert Matter? International Review of Financial Analysis, 55(March 2017), 170-183. https://doi.org/10.1016/j.irfa.2017.11.002

Zuckerman, M. (1994). Behavioral Expressions and Biosocial Bases of Sensation Seeking. (Vol. 18, Issue 6). Cambridge: Cambridge University Press. 